Reseñas

\title{
Osvaldo Barreneche. De brava a dura. Policía de la Provincia de Buenos Aires. Una historia (1930-1973). Rosario: Prohistoria/Ediciones, 2019, 172 páginas. Nicolás López
}

\section{López, Nicolás}

Nicolás López nicolaslopezcalvino@hotmail.com Universidad Nacional de Rosario, Argentina

\author{
Avances del Cesor \\ Universidad Nacional de Rosario, Argentina \\ ISSN: 1514-3899 \\ ISSN-e: $2422-6580$ \\ Periodicidad: Semestral \\ vol. 17 , núm. 23,2020 \\ revistaavancesdelcesor@ishir-conicet.gov.ar \\ Recepción: 26 Mayo 2020 \\ Aprobación: 20 Julio 2020 \\ URL: http://portal.amelica.org/ameli/jatsRepo/27/271572009/ \\ index.html \\ DOI: https://doi.org/10.35305/ac.v17i23.1294
}

\section{(i) (9)}

Esta obra está bajo una Licencia Creative Commons AtribuciónNoComercial 4.0 Internacional.

La propuesta de Osvaldo Barreneche nos lleva a recorrer cinco décadas del siglo XX bonaerense en las cuales pasó de todo y, dentro de esa historia y de este "todo", la policía nunca estuvo al margen. El libro no pretende tener una vocación generalista de la historia de la policía sino, como su título bien lo expresa, la de una historia de la policía bonaerense entre los años 1930 y 1973 . Se busca mostrar las particularidades que existieron dentro de esta institución, desmontando la imagen monolítica que existe alrededor de la policía y por tanto descubrir sus numerosas fisuras.

"De brava a dura" se trata de un estudio, cuyo núcleo argumentativo intenta explicar cinco problemáticas que se dieron al interior de la institución policial: las constantes reformas a la cual fue sometida, la construcción de una identidad al interior de la misma, la formas en que eran juzgados sus miembros, los problemas de corrupción y violencia y, por último, las debates que se dan en torno a la figura del agente policial como trabajador. Estas problemáticas tienen a 1930 
como punto de partida, sin embargo, en varios pasajes se retrotrae a comienzos del siglo XX. Mucho del contenido del libro dialoga permanentemente con la abundante historiografía que ha estudiado las policías en los años precedentes. De esta manera, 1930 es más una referencia que un comienzo preciso. Por otro lado, 1973 es el punto de arribo, una fecha que no es traspasada. La investigación se inserta entre dos fuertes producciones historiográficas: la de comienzos del siglo XX y la denominada "historia reciente". En este sentido, uno de los objetivos que se plantea es dar cuenta de lo que sucedió en este espacio intermedio y de ahí su título: "De brava a dura", adjetivos con los cuales fue descripta la policía bonaerense. La "brava" de los años treinta y la "dura" de los setenta.

La introducción consta de una breve contextualización historiográfica de las distintas líneas de investigación referidas al mundo policial, de la justicia y del delito. Aquí se marcan dos períodos, uno caracterizado por la proliferación de historias oficiales, las cuales han contribuido a la difusión de información básica sobre las fuerzas de seguridad y la ubicación de ciertos archivos. La otra, a partir de la década de 1980, durante el proceso de transición a la democracia en la Argentina, en el que se despertó el interés desde la Ciencias Sociales por la historia de las instituciones de seguridad, y donde hubo un predominio fundamental por el período del terrorismo de Estado. Ya para la década de 1990 aparecen trabajos sobre las relaciones cívico-militares, surgiendo una mirada orientada al análisis del funcionamiento de las instituciones policiales y de sus vínculos con el sistema político y la sociedad. Para finales de la década de 1990 y comienzos del nuevo siglo se suman los aportes de los historiadores, así los estudios sobre la historia de la justicia y las policías en América Latina fueron adquiriendo un mayor interés por saber el pasado de las agencias estatales de control. Estas indagaciones tuvieron horizontes más amplios dando lugar a trabajos centrados en la historia del delito, del control social, de la violencia y sus repercusiones culturales.

En el primer capítulo- "Reformas permanentes"- Barreneche desarrolla los constantes intentos de reformas que se experimentaron en la policía bonaerense desde 1930 hasta 1973. El análisis comienza por los intentos de Manuel Fresco, gobernador de la provincia entre 1936-1940, por quebrar las lealtades locales entre policías y caudillos políticos. Las medidas apuntaron a generar que el liderazgo de la fuerza recayera en el Jefe de la Policía y en la figura del gobernador. Siguiendo un orden cronológico, continúa con las reformas que se dieron durante el peronismo. Este apartado ahonda en los intentos de cambios encabezado por Mercante y Marsillach, donde se puso atención en el reforzamiento de la "cadena de mando". También, es interesante la reconstrucción que hace Barreneche de cómo la nueva policía peronista comienza a integrar una red de contención social, la cual se encuentra concadenada con los cambios que se dan en la formación de cadetes. El capítulo cierra con una breve explicación de la "desperonización" de las fuerzas policiales luego de la Revolución Libertadora y la puesta en marcha del Plan Conintes (Conmoción Interna del Estado). A lo largo del texto, se intenta demostrar los constantes avances y retrocesos en los cuales se vieron involucrados la institución policial y el poder político provincial.

En el capítulo II titulado "Los orígenes de la "familia policial", el autor trata de darle historicidad a un concepto que genera confusión o, mejor dicho, que tiene límites y contornos difusos. La pregunta que recorre todo el capítulo es ¿quiénes componen la familia policial? Para responderla, Barreneche retrocede del año '30 
a finales del siglo XIX para explicar los orígenes del término relacionado en sus comienzos a la asistencia a los policías y parientes. El concepto de familia policial se fue estructurando en un sistema de beneficios sociales y de posibilidades de hacer carrera dentro de la institución. Las mayores concreciones, según el autor, hacen carne a partir de la década de 1940, cuando los beneficios se extienden a los familiares y a la creación de espacios de sociabilización.

"Justicia por mano propia" es el título del capítulo tres, en el que se analizan las coyunturas bajo las cuales se puso en marcha la llamada Justicia Policial en el espacio de la provincia de Buenos Aires. Este resulta uno de los puntos más fuertes e interesantes del trabajo. Aquí explica el traspaso de los fueros judiciales a la propia policía para que sean juzgados por sus pares o superiores en delitos comunes. El análisis parte de los últimos años del gobierno peronista y acompaña todo el tránsito de esta experiencia que comienza en la Policía Federal y luego decanta en las provinciales. La cesión de un fuero propio estuvo acompañada de intereses políticos y de una búsqueda de lealtad de la institución policial a la figura de Perón. Buena parte de esta explicación aparece tras el prisma de los debates originados. Al momento de recorrer las fuentes de las cuales, hay una gran presencia de discursos, tanto a favor como en contra, dados en el Congreso de la Nación a la hora de aprobar esta nueva ley. El trabajo, también reconstruye de una manera muy lograda el impacto que tuvo la aplicación de la justicia policial al interior de la propia fuerza. Repasa cuáles eran las condenas, quiénes eran los infractores, cuáles eran los criterios a la hora de juzgar a sospechosos. Recorre así una serie de prácticas desplegadas por los gobiernos y por la institución policial, en donde nuevamente el impacto de estos cambios no fue homogéneo.

El capítulo IV- "Corrupción y violencia"- resulta central ya que plantea el tránsito de una policía brava a dura. El avance de la violencia policial es abordado por el autor de forma minuciosa a pesar de las dificultades para acceder a las fuentes, circunstancia que pone límites a la profundización de la problemática. Marca como quiebre el año 1955, momento en que la policía es reorganizada nuevamente luego de los años peronistas y comienza a incrementar su violencia sobre aquellos que debía proteger, para terminar en lo que luego en los años setenta fue el terrorismo de Estado. La violencia no era una práctica nueva en la fuerza, sin embargo, a partir del ' 55 presenta novedades que son analizadas, las más importante fue que los agentes contaran con el aval de autoridades policiales, políticas y judiciales del más alto nivel, mientras que en la década de 1930 lo hacían por cuenta y riesgo de cada uno de los caudillos políticos locales. En este capítulo introduce a otro sujeto, la justicia penal, la cual operó con cautela y reserva frente a las denuncias presentadas por terceros. En los expedientes analizados, el autor comprueba cómo jueces tomaron ciertas medidas legales correspondientes (generalmente recaían sobre los miembros más jóvenes y de menor rango) y, al mismo tiempo, desestimaron muchas acusaciones.

El último capítulo, titulado "Las y los policías como trabajadores" se encuentra relacionado con debates actuales sobre la sindicalización o no de los policías. Aquí el autor busca aportar una perspectiva histórica de las distintas formas de protesta, muchas veces de forma anónima y otras veces presenciales, en las cuales los agentes buscaron hacer escuchar sus reclamos por las condiciones de trabajo. Barreneche comprueba nuevamente su hipótesis central, que la policía de Buenos Aires no era un todo homogéneo, ya que la conducción de las protestas eran 
oficiales jóvenes y representaban a los estamentos inferiores de la fuerza. Esto se pude ver particularmente en la reconstrucción de la huelga de 1973, la cual se encuentra explicada de forma clara y precisa.

Al comienzo del "Epílogo" el autor expone nuevamente de una forma acotada las principales líneas de estudio sobre las instituciones de seguridad como también las dificultades que surgen a la hora de estudiarlas, principalmente aquellas referidas al acceso a las fuentes. A su vez, señala la vacante existente de una historia reciente de las policías ya que el grueso de los estudios es referenciado a un período lejano, principalmente a los años previos al peronismo.

En síntesis, el libro constituye un aporte significativo para los estudios policiales, como también para la historia social, por su importante trabajo de archivo mediante el rastreo de fuentes, principalmente en lo referido al método de análisis tanto de forma cualitativa como comparativa. La investigación avanza eficazmente en la tarea desmontar y señalar las particularidades existentes en una fuerza que a priori manifiesta una cierta homogeneidad en su forma de pensamiento y en su accionar. Otra de las virtudes es el recorte temporal, donde existe una vacancia en la materia, dejando una serie de preguntas a futuros trabajos. 